\title{
Influence of Infill Wall Configuration on Failure Modes of RC Frames
}

\author{
Xiaojie Zhou (D), Xiaoyuan Kou, Quanmin Peng, and Jintao Cui \\ Tianjin Key Laboratory of Civil Buildings Protection and Reinforcement, Tianjin Chengjian University, \\ 26 Jinjing Road, Xiqing District, Tianjin, China \\ Correspondence should be addressed to Xiaojie Zhou; zhouxj88888@126.com
}

Received 20 January 2018; Accepted 11 April 2018; Published 25 June 2018

Academic Editor: Salvatore Russo

Copyright (C) 2018 Xiaojie Zhou et al. This is an open access article distributed under the Creative Commons Attribution License, which permits unrestricted use, distribution, and reproduction in any medium, provided the original work is properly cited.

\begin{abstract}
An improper configuration of masonry infill walls in RC frame may lead to short column effect on the columns, which is harmful to the seismic behavior of the structure. In this study, a bare frame and two single-story, single-bay RC frames, partially infilled with masonry, were tested under cyclic loading. The failure mechanism and seismic performance of these partially infilled RC frames (with an infill height of $600 \mathrm{~mm}$ ) with different types of connections were analysed. Based on the experiment, nonlinear finite element simulation and analysis were conducted to study the effects of the infill walls and connections. The results show that both mechanical performance and failure mode are affected by the infill height, the type of connection between the frame and the infill, and the ratio of shear bearing capacity of the frame column to that of the infill. For the masonry-infilled frame with rigid connection, the higher the infill wall is, the lower the shear bearing capacity ratio will be. Thus, the effect of the lateral constraint of the infill wall on the column increases, and the shear span ratio of the free segment of the column decreases, resulting in the short column effect. Based on the analysis results, a value of 2.0 is suggested for the critical shear bearing capacity ratio of the frame column to the infill wall. If the shear bearing capacity ratio is less than 2.0 and the shear span ratio of the column free segment is not more than 2.0, the short column effect will occur. For the infilled frame with flexible connection, both the lateral constraint from the wall to the column and the wall-frame interaction decrease; this reduces or prevents the short column effect. The conclusion can present guidance for the design and construction of masonry-infilled RC frame structure.
\end{abstract}

\section{Introduction}

A large number of earthquake investigations have revealed that nonstructural members, especially the masonry infill walls, may have a large influence on the seismic behavior of the main structure. In some cases, the effect may be positive, but in other cases the masonry infill walls may cause more serious damage to the framed structure. In the recent decades, extensive studies [1-7] have been conducted on this topic using model experiments or numerical analysis.

For ease of construction and to ensure the stability of the infill wall, tie bars and cement mortar are embedded between the wall and frame to form a rigid connection. With a rigid connection, the mechanism of force transfer changes because of the presence of wall-frame interaction $[8,9]$. When the infill walls are arranged unevenly, the interaction may cause structural failures such as soft-story damage or torsion damage [10-12]. In addition, to incorporate window or door openings in the walls, the frames are partially infilled. Thus, the column is kept captive by the infill wall, and only a segment can deform laterally; this structure will be prone to short column effect, which is harmful to seismic performance [13, 14]. Then the "strong frame-weak infill" criterion which can form a two-line system of defense and prohibit the brittle shear failure in columns was proposed by Huang [15] for the seismic design of infilled frame structures. Other literature review shows that using isolator subframes or flexible connection between the wall and frame can reduce the wall-frame interaction and improve the seismic performance [16-22]. In a flexible connection, a gap is left between the wall and the RC frame. 
TABLE 1: Description of specimens.

\begin{tabular}{lccc}
\hline Specimen number & $\begin{array}{c}\text { Connection } \\
\text { between the wall } \\
\text { and frame }\end{array}$ & Connection between the wall and frame column & Height of infill wall \\
\hline PF & Bare frame & - & Core column \\
\hline GWF & Rigid connection & $\begin{array}{c}\text { Tie bars into the column and wall; the } \\
\text { longitudinal reinforcement of core column } \\
\text { stretches into the sill. }\end{array}$ & $\begin{array}{c}\text { Partially infilled } \\
\left(H_{\mathrm{w}}=600 \mathrm{~mm}\right)\end{array}$ \\
\hline RWF & $\begin{array}{c}\text { Flexible } \\
\text { connection }\end{array}$ & $\begin{array}{c}\text { Tie bars into the column and wall; tie bars and } \\
\text { steel mesh reinforcement were connected through } \\
\text { the wall; foam polystyrene filled seam reserve; the } \\
\text { longitudinal reinforcement of core column } \\
\text { stretches into the sill. }\end{array}$ & $\begin{array}{c}\text { Partially infilled } \\
\left(H_{\mathrm{w}}=600 \mathrm{~mm}\right)\end{array}$ \\
\hline
\end{tabular}

In this study, a bare frame and two single-story, single-bay $\mathrm{RC}$ frames partially infilled with masonry were tested under reversed cyclic loading. The failure mechanism and the seismic performance of these partially infilled RC frames with different types of connections were analysed; the details are presented in the next section. Based on the results of the experiment, nonlinear finite element analysis was performed to investigate the effect of infill wall on the mechanical performance of the frame structures; the analysis was performed with several parameters. The details are covered in Section 3. In particular, the effects of infill height and the shear bearing capacity ratio of the frame column to the infill wall on the failure modes of the frame columns with rigid connection were examined to obtain the critical value of the shear bearing capacity ratio. Further, the influence of flexible connection in reducing the short column effect was investigated. Finally, based on the results of the experiment and numerical simulation, several important conclusions related to design and construction were obtained, which would be useful for the antiseismic design and safety assessment of partially infilled $\mathrm{RC}$ frames in practical applications.

\section{Experimental Programme}

2.1. Specimens. Three single-story, single-bay masonry-infilled RC frames were tested under low reversed cyclic loading. The masonry infill wall was built with fly-ash thermal insulation consisting of a hollow block of grade MU3.5 and masonry mortar of type M5. Concrete types of grades C30 and $\mathrm{C} 20$ was used for fabrication of the RC frames and core columns, respectively. The stirrups and longitudinal bars of the RC frames were made of HPB300 and HRB335, respectively. The axial compression ratio of the frame columns was 0.25 . For the specimen with flexible connection, a gap of 30 $\mathrm{mm}$ between the walls and the frames was reserved to meet the displacement angle of the weak layer in the case of frequent earthquakes and rare earthquakes, and the gap was infilled with $32 \mathrm{~mm}$ thick polystyrene foam boards between the walls and the frames. The details of the specimens are presented in Table 1, and the dimensions and reinforcements of the frame are shown in Figures 1 and 2.

2.2. Test Setup and Instrumentation. The test setup is shown in Figure 3. Axial force was applied up to the desired value and kept constant on each column by two hydraulic jacks. For moving the jacks during lateral loading, low-friction sliding plates were placed on the jacks. Cyclic lateral load was applied at the end of the beam by an electrohydraulic actuator. The lateral loading history is shown in Figure 4. Before yielding of the specimen, one fully reversed loading cycle was applied at each displacement amplitude level, and three cycles were applied after yielding. Failure was assumed to occur when the strength of the specimen reduces by more than $15 \%$ of the peak strength.

Strain gauges were placed on the stirrups and longitudinal bars of the RC frames at the critical sections, as shown in Figure 5, to monitor the behavior of the steel bar during the tests.

\subsection{Experimental Results and Analysis}

2.3.1. Failure Modes. The final failure modes of the specimens are shown in Figure 6.

(1) Specimen PF: The longitudinal bars of the frame yielded first at the ends of the beam and columns at the drift ratio of $\Delta=h / 200(h=1380 \mathrm{~mm})$. With the increase in amplitude, plastic hinges developed at the ends of the beam and columns. Yielding of stirrups was not observed during the entire test. Thus, the failure mode of this specimen was a typical flexural failure.

(2) Specimen GFW: Because of the stiffness effect of the infill wall on the column, at the drift ratio of $\Delta=h / 300$, the longitudinal bars yielded first at the ends of the beam prior to the columns. At the drift ratio of $\Delta=h / 100$, diagonal cracks appeared at the lower part of the frame column, and the stirrups yielded. These phenomena occurred owing to the presence of the infill wall that was rigidly connected to the frame. Then, the longitudinal bars of the columns yielded at the lower part at the drift ratio of $\Delta=h / 70$. Finally, plastic hinges developed at the ends of the beam and the column. Thus, the failure mode of the beam was a typical bending failure, while that of the column was a flexural-shear failure, as it exhibited the features of both bending and shear failures. Because of the thrust between the frame and the wall, the masonry suffered serious damage.

(3) Specimen RFW: As the gaps were infilled with polystyrene foam boards, the stiffness effect and the constraint effect of the infill wall on the column decreased, and hence 


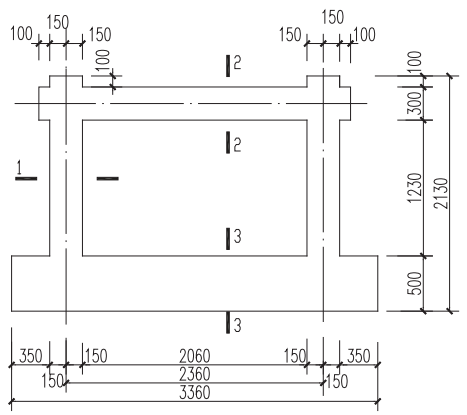

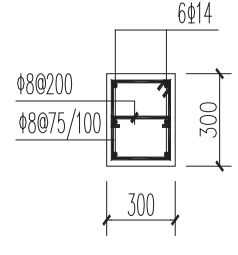

$1-1$

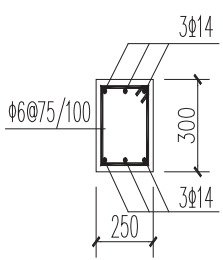

$2-2$

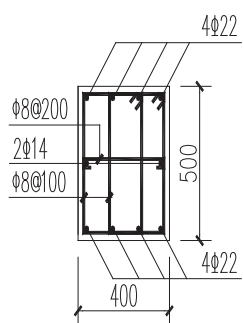

$3-3$

FIGURE 1: Geometry and reinforcements of specimens.

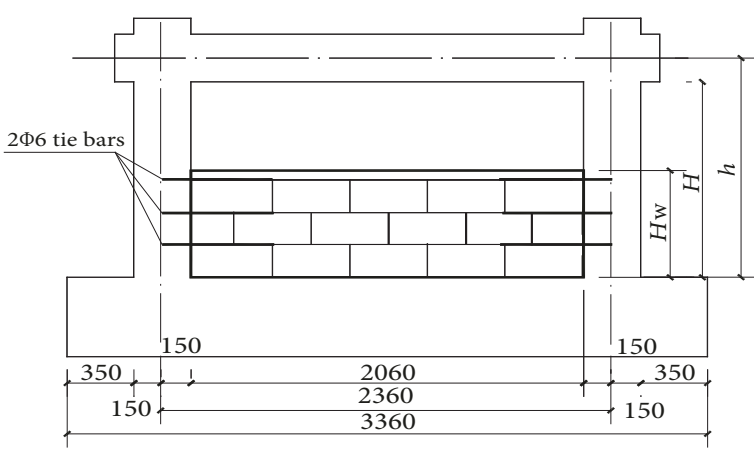

(a) Specimen GWF. Note: (1) $2 \phi 6$ tie bars fixed $150 \mathrm{~mm}$ into the column and $350 \mathrm{~mm}$ into the wall. (2) The core columns are set up on both ends of the infill wall. There are $4 \phi 6$ longitudinal bars in columns which are embedded $200 \mathrm{~mm}$ into the bottom beam. (3) There is a layer of plain concrete on the window sill

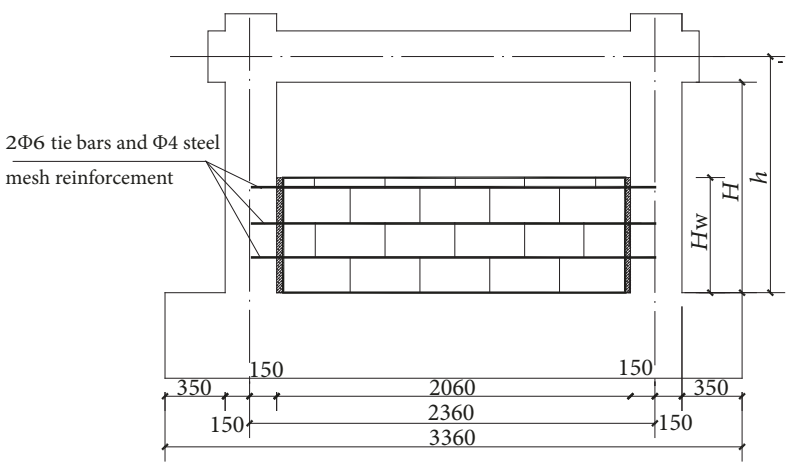

(b) Specimen RWF. Note: (1) $2 \phi 6$ tie bars and $\phi 4$ steel mesh reinforcement were connected through the wall. (2) The core columns are set up on both ends of the infill wall. There are $4 \phi 6$ longitudinal bars in columns which are embedded $200 \mathrm{~mm}$ into the bottom beam. (3) There is a layer of plain concrete on the window sill. (4) There is a gap of 30 $\mathrm{mm}$ that is infilled with foam board between the wall and frame

FIGURE 2: Specimens GWF and RWF.

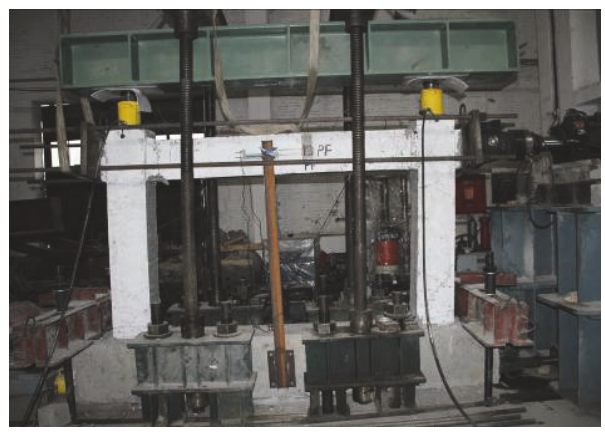

(a) Test setup

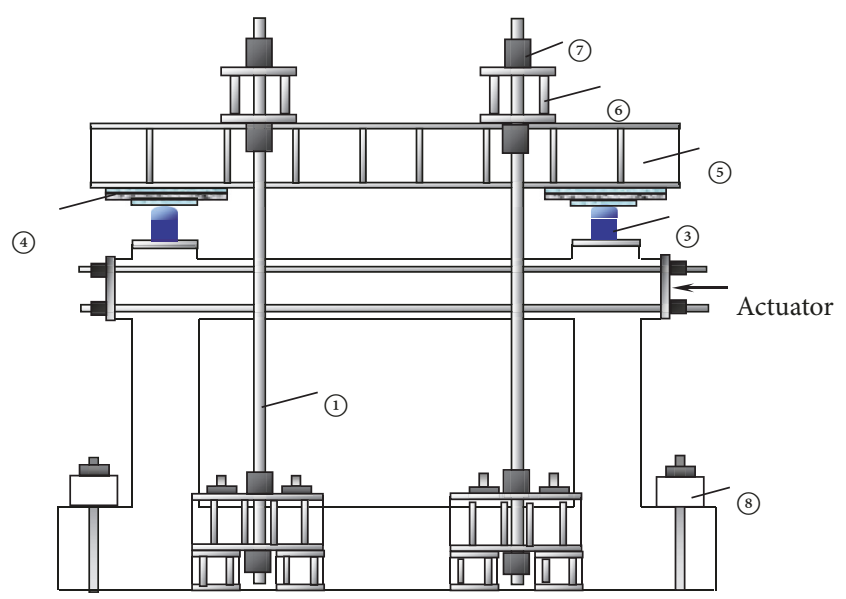

(b) Schematic of test setup. Note: (1) vertical loading device; (2) frame; (3) jack; (4) Low-friction sliding plate; (5) steel beam; (6) steel crossbeam; (7) bolt; (8) pressure beam

Figure 3: Test setup. 


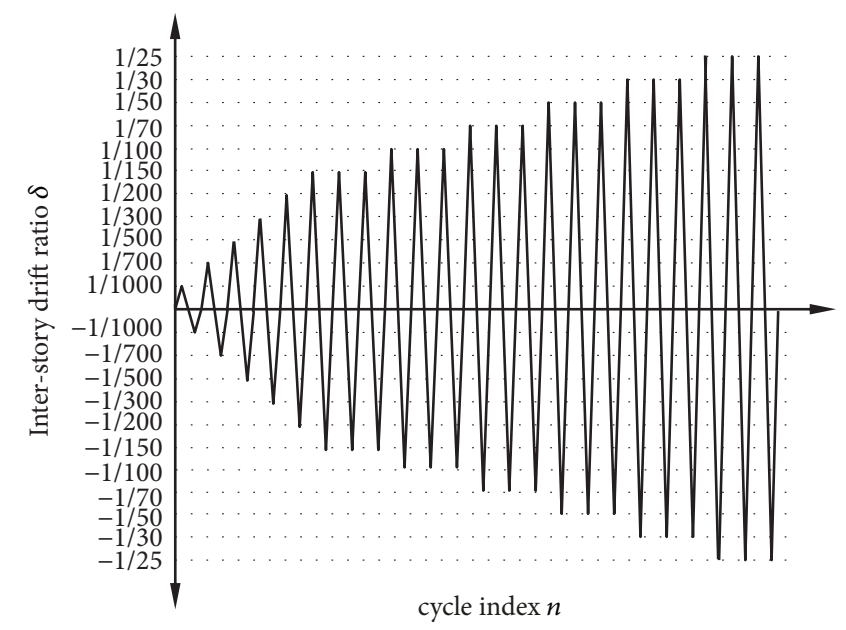

FIGURE 4: Loading history.

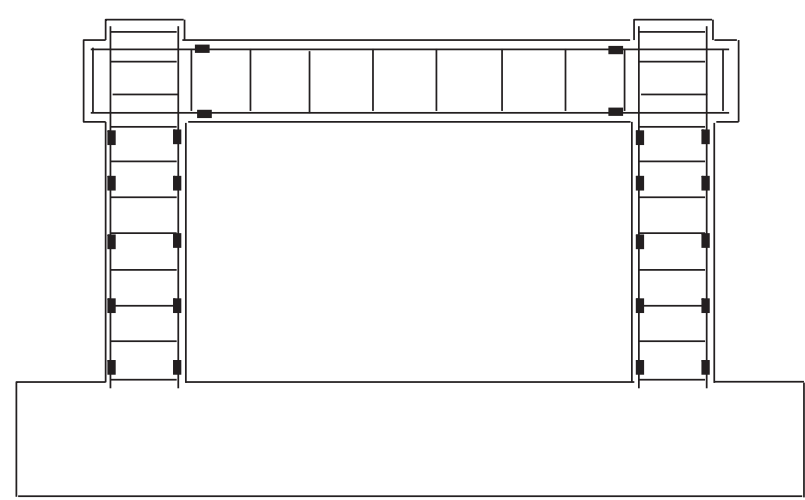

(a) Strain gauge layout in the longitudinal bars

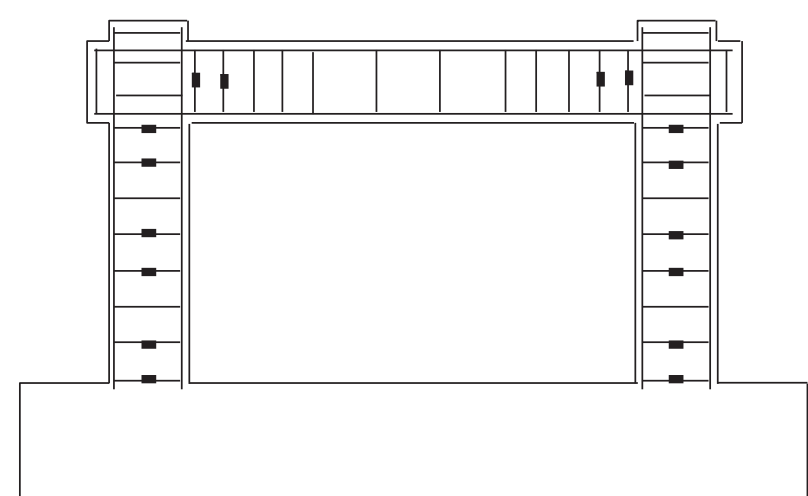

(b) Strain gauge layout in the stirrups

FIGURE 5: Strain gauge layout in the bars of beams and columns.

the longitudinal bars yielded at the ends of the beam and the column at the drift ratios of $\Delta=h / 200$ and $\Delta=h / 100$, respectively. Subsequently, plastic hinges developed progressively at the ends of the beam and the column with the increase in cyclic load. As there was no yielding of stirrups during the entire test, the failure mode of this specimen was a typical flexural failure. Because of the minor thrust between the frame and the wall, the masonry suffered only minor damage.

To sum up, for the specimen with rigid connection, the wall-frame interaction may give rise to additional shear on the frame column, which affects the failure modes and makes the structure vulnerable to damage under seismic action. For the specimen with flexible connection, the additional shear and short column effect can be reduced or even avoided. In this experiment, the infill wall which was rigidly connected to the RC frame did not have a significant effect on the behavior of the frame column because of the low strength of the infill wall. Otherwise, the short column effect may occur in the frame columns.

2.3.2. Hysteresis Curves and Cumulative Energy Dissipation. Figures 7 and 8 show the force-displacement hysteresis curves and the relationship between cumulative energy dissipation and displacement, respectively, for the specimens.

The same features can be seen in all the specimens until the specimens yielded. Before the crack load is reached, the relationship between the force and displacement was linear, and the energy dissipation was low. Subsequently, the hysteresis loop became spindle-shaped, indicating that the energy dissipation capacity has increased.

After yielding, however, the behaviors of the specimens were slightly different from each other. For specimens PF and GFW, the hysteresis loop became bow-shaped initially, and the energy dissipation increased; when the maximum load was reached, pinching effect was significant, and the bearing capacity as well as the energy dissipation capacity decreased. It may be noted that the area bounded by the hysteresis loop of specimen GFW was larger than that of specimen PF, implying higher energy dissipation at the same drift ratio. Finally, the hysteresis loop of specimen PF had a reversed S-shape, while that of specimen GFW had a shape lying between bowshape and reversed S-shape. It can be inferred that the energy dissipation capacity of the structure improved because of the infill wall. For specimen RFW, the pinching effect was not 


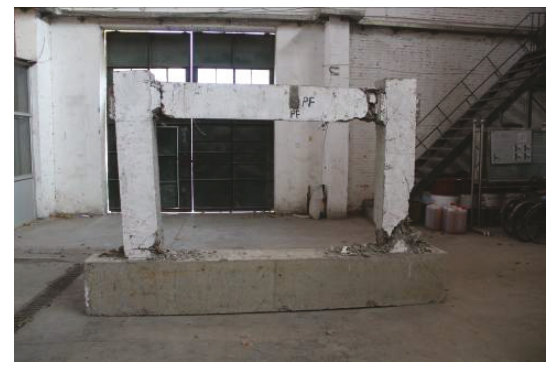

(a) Specimen PF

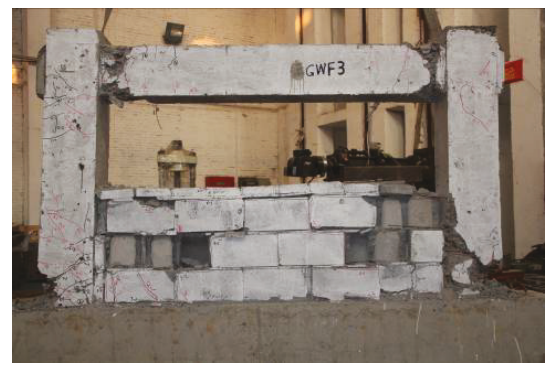

(b) Specimen GWF

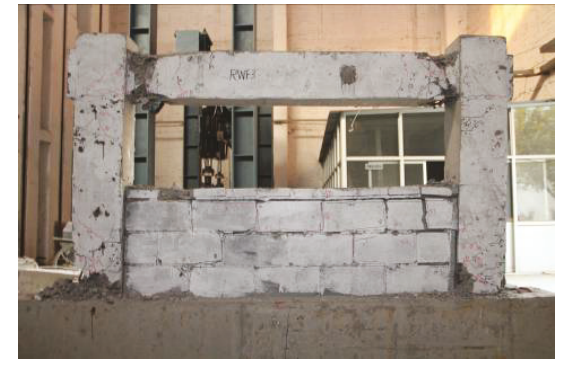

(c) Specimen RWF

FIGURE 6: Strain gauge layout in the bars of beams and columns.

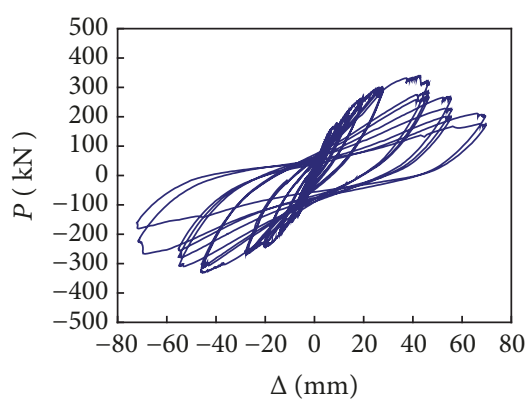

(a) Specimen PF

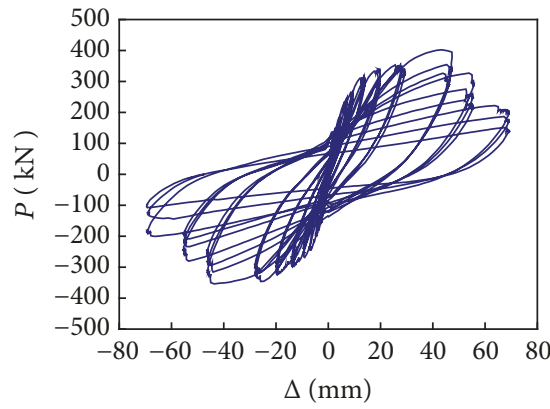

(b) Specimen GWF

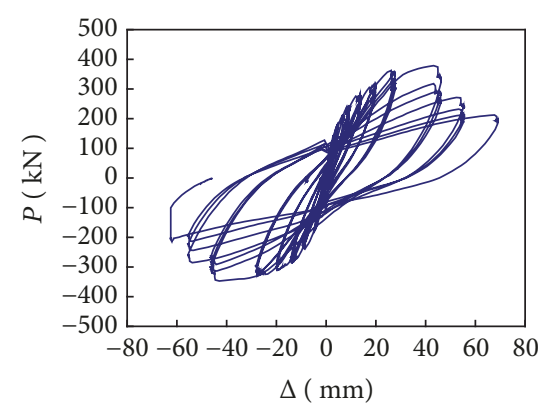

(c) Specimen RWF

Figure 7: Hysteresis curves of specimens.

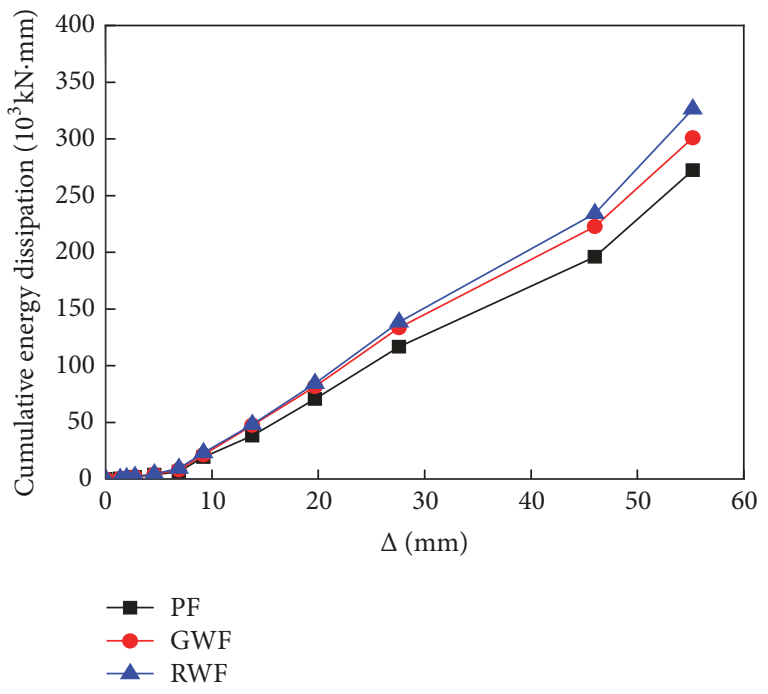

FIGURE 8: Relationship between cumulative energy dissipation and displacement.

significant initially owing to the flexible connection. Hence, the hysteresis loop was basically bow-shaped, and the area bounded by the hysteresis loop was large. On reaching the maximum load, the pinching effect could be observed, and the loop had a shape lying between spindle-shape and bowshape. Compared with specimen GFW, the energy dissipation capacity of specimen RFW had improved.
Normally, a frame partially infilled with masonry can have a high energy dissipation capacity; however, with a rigid connection, which may cause an additional shear or short column effect, shear failure of the frame column can occur. Therefore, the flexible connection was an effective solution, as the specimen with flexible connection dissipated more energy than that with rigid connection.

2.3.3. Skeleton Curves. Figure 9 shows the skeleton curves of the specimens. The characteristic points on the curves include cracking points, yielding points, peak points, and failure points. The cracking point corresponds to the load and displacement when the first connected crack appears in the infill wall. Similarly, the yielding point corresponds to the load and displacement when the longitudinal bars of frame columns yield and is determined by the energy equivalent area method based on the skeleton curve. The failure point corresponds to the load 15\% less than the peak load and the corresponding displacement. The tested values of these characteristic points are presented in Table 2.

From the details in Figure 9 and Table 2, the following observations can be made.

(1) The cracking load of specimen RWF with flexible connection is high as a result of infilling in the gaps provided in the frame, which decreases the wall-frame interaction and delays the occurrence of cracks.

(2) Compared with the maximum load for specimen PF, the maximum loads of specimens GWF and RWF are higher by $12.3 \%$ and $7.8 \%$, respectively. Thus, the addition of infill wall contributes to higher bearing capacity of the structure. 
TABLE 2: Experimental results.

\begin{tabular}{lcccccccccc}
\hline Specimens & $\begin{array}{c}P_{\mathrm{cr}} * \\
(\mathrm{kN})\end{array}$ & $\begin{array}{c}\Delta_{\mathrm{cr}} \\
(\mathrm{mm})\end{array}$ & $\begin{array}{c}P_{\mathrm{y}} \\
(\mathrm{kN})\end{array}$ & $\begin{array}{c}\Delta_{\mathrm{y}} \\
(\mathrm{mm})\end{array}$ & $\begin{array}{c}K_{\mathrm{efw}} \\
\left(\mathrm{kN} \cdot \mathrm{mm}^{-1}\right)\end{array}$ & $\begin{array}{c}P_{\max } \\
(\mathrm{kN})\end{array}$ & $\begin{array}{c}\Delta_{\max } \\
(\mathrm{mm})\end{array}$ & $\begin{array}{c}P_{\mathrm{u}} \\
(\mathrm{kN})\end{array}$ & $\begin{array}{c}\Delta_{\mathrm{u}} \\
(\mathrm{mm})\end{array}$ & $\mu=\Delta_{\mathrm{u}} / \Delta_{\mathrm{y}}$ \\
\hline PF & - & - & 166.3 & 9.59 & 17.34 & 334.7 & 44.37 & 284.5 & 55.28 \\
\hline GWF & 188 & 4.64 & 263.3 & 9.10 & 28.93 & 375.9 & 43.21 & 319.5 & 51.58 & 5.67 \\
\hline RWF & 241.8 & 7.77 & 260.0 & 9.65 & 26.94 & 360.7 & 44.90 & 306.6 & 55.97 & 5.80 \\
\hline
\end{tabular}

$* P_{\mathrm{cr}}, P_{\mathrm{y}}, P_{\max }$, and $P_{\mathrm{u}}$ : the loads of the specimens corresponding to the cracking point, yielding point, peak point, and failure point, respectively; $\Delta_{\mathrm{cr}}, \Delta_{\mathrm{y}}$, $\Delta_{\max }$, and $\Delta_{\mathrm{u}}$ : the displacements of the specimens corresponding to the cracking point, yielding point, peak point, and failure point, respectively; $K_{\mathrm{efw}}$ : the equivalent interlayer lateral stiffness of the masonry-infilled frame, $K_{\mathrm{efw}}=P_{\mathrm{y}} / \Delta_{\mathrm{y}} ; \mu$ : the displacement ductility coefficient.

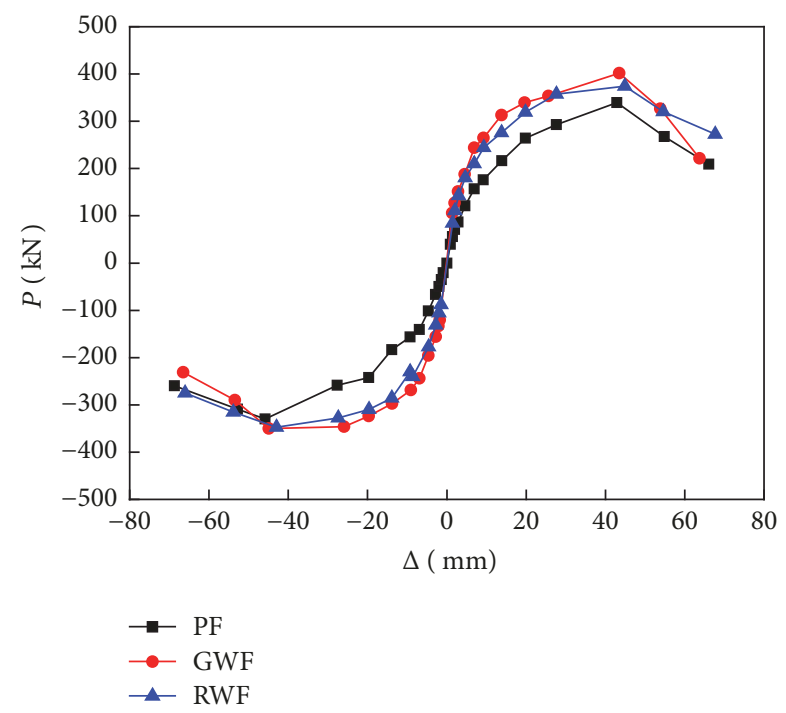

FIGURE 9: Skeleton curves of specimens.

(3) Compared with the stiffness of specimen PF, the stiffness values of specimens GWF and RWF are higher by $66.8 \%$ and $55.4 \%$, respectively. Thus, the addition of infill wall contributes to higher stiffness of the structure.

(4) The displacement ductility values of the partially infilled frame $\left(H_{\mathrm{w}}=600 \mathrm{~mm}\right)$ for specimen GWF and specimen RWF are similar to the value for specimen PF according to this test.

2.3.4. Strain in Longitudinal Reinforcement. The strain in the longitudinal bars during the test is depicted in Figure 10. The following observations can be made.

(1) For specimen PF, the strain in the longitudinal bar developed linearly in the column height direction. As the stiffness of the base beam was greater than that of the top beam, the strain at the bottom end of the column was greater than that at the top.

(2) For specimen GWF with rigid connection, the strain in the longitudinal bar at half the height of the column increased sharply owing to the stiffness effect and constraining effect resulting from the infill wall and the rigid connection. The internal force of the column was distributed unevenly and discontinuously, leading to a change in the position of the critical section of the column. If the shearing capacity of the infill wall is greater than that of the frame, the column may fail in shear.

(3) For specimen RWF with flexible connection, the strain in the longitudinal bar had almost a linear variation in the column height direction, owing to the reduction in both the stiffness effect and restraining effect of the infill wall. Consequently, the critical section of the column was at the bottom.

It can be concluded that in the case of rigid connection between the wall and frame, improper infill wall configuration may cause additional shear or even short column effect on the frame column, which is harmful to the seismic performance of the structure. The strength and height of the masonry infill as well as the type of connection between the wall and frame will affect the structural behavior and failure mode in most cases.

\section{Nonlinear Finite Element Analysis}

\subsection{Model Establishment and Verification}

3.1.1. Model Establishment. Using ABAQUS finite element software, three-dimensional models were established and nonlinear finite element analysis was performed on the masonry-infilled frames under monotonic horizontal load. The finite element model of specimen RWF is shown in Figure 11. The bottom of the columns and the infill wall were well anchored with the base. A vertical load was applied on the top of each column and a monotonic horizontal load with displacement increment was applied at the right end of the top beam, as done during the test. C3D8R element was adopted for the concrete frame, infill wall, core column, and foam board; T3D2 truss element was adopted for the reinforcements embedded in the concrete. Reinforced core columns were placed at the two ends of the masonry wall. Binding constraint was applied on the wall-frame interfaces, frame-foam board, and wall-foam board. The strength and elastic parameters of the materials are listed in Tables 3 and 4, respectively.

The bilinear ideal elastic-plastic model was adopted for the reinforcements. The plastic damage model of ABAQUS and the constitutive relation recommended by the Chinese Code for Design of Concrete Structures (GB 50010-2010) were used for the concrete. For the masonry wall, the compression constitutive relation was adopted as given in the literature [24]; the tensile constitutive relation was taken as given in the literature [25]; and the elastic modulus in compression was considered the same as that in tension; only the 


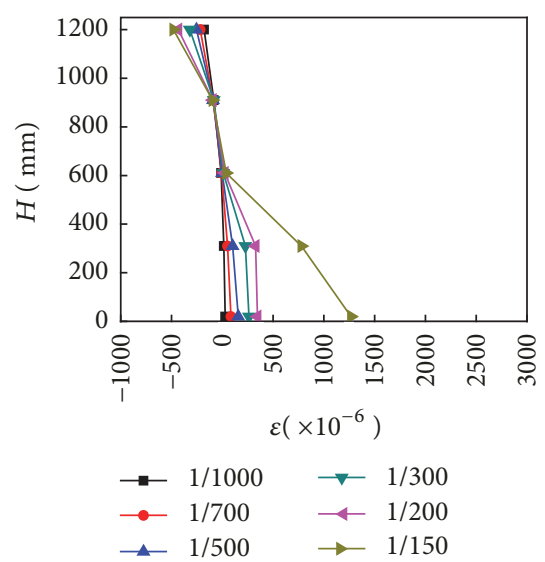

(a) Specimen PF

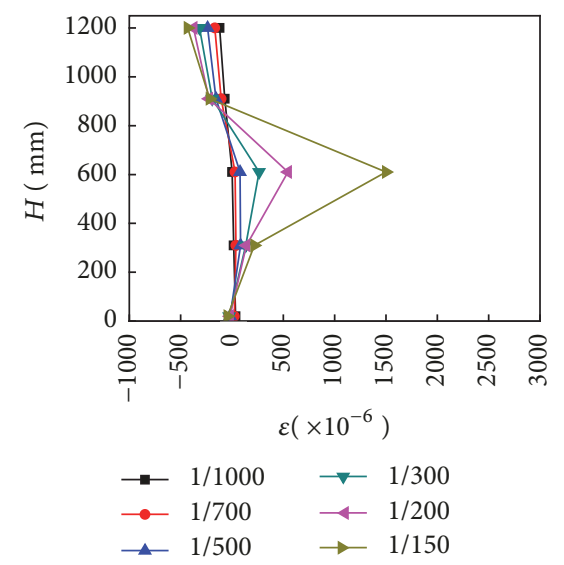

(b) Specimen GWF

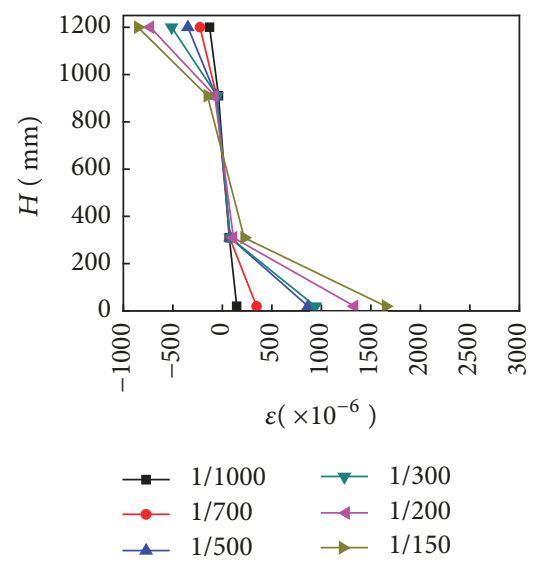

(c) Specimen RWF

FIgURE 10: Strain in the longitudinal bars of the left column.

TABLE 3: Strength parameters of the materials.

\begin{tabular}{lcccccc}
\hline Type & Masonry & $\begin{array}{c}\text { Longitudinal } \\
\text { reinforcement of } \\
\text { frame }\end{array}$ & $\begin{array}{c}\text { Column } \\
\text { stirrup }\end{array}$ & $\begin{array}{c}\text { Beam stirrup and core } \\
\text { column reinforcement }\end{array}$ & $\begin{array}{c}\text { Concrete used in } \\
\text { frame }\end{array}$ & $\begin{array}{c}\text { Concrete poured in } \\
\text { core column }\end{array}$ \\
\hline $\begin{array}{l}\text { Compression } \\
\text { strength (MPa) }\end{array}$ & 1.02 & 483.8 & 365.6 & 381.2 & 20.5 & 22.3 \\
\hline $\begin{array}{l}\text { Tensile strength } \\
(\mathrm{MPa})\end{array}$ & 0.021 & 483.8 & 365.6 & 381.2 & 2.26 \\
\hline
\end{tabular}

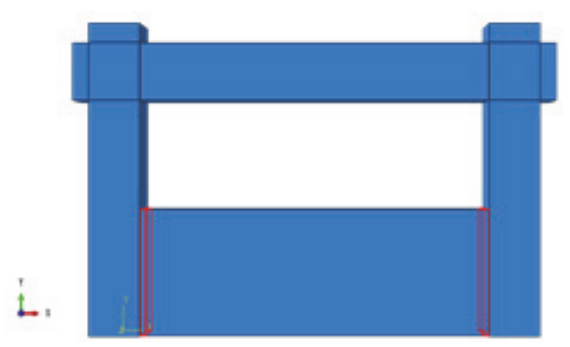

FIGURE 11: Finite element model of specimen RWF.

compression features of the foam board were considered and the graph of yield stress versus plastic strain curve is shown in Figure 12.

3.1.2. Model Verification. The comparison of the experimental and analytical results is shown in Figure 13. The test skeleton curves were obtained for the case of reverse cyclic loading, while the analytical skeleton curves were obtained for the case of monotonic load. Some differences are observed between the analytical and experimental results because of neglecting the variation in material damage under reverse cyclic loading in the finite element analysis; however, the curves for the analytical results basically agree with those for the experimental results.

The comparison of plastic damage in compression obtained from the models and the failure phenomenon observed in the experiment is shown in Figure 14. As shown in the figure, the analytic results are nearly consistent with the experimental results. The damage to the frame was mainly on the beam and column ends and short column effect did not occur, as the lateral constraint on the frame column is weak owing to the lower strength of the masonry. Thus, the failure mode of all the specimens was bending failure, and the flexible connection further mitigated the damage to the wall and frame.

\subsection{Influence of Shear Bearing Capacity Ratio of the Frame Column to the Infill Wall on the Failure Mode}

3.2.1. Shear Bearing Capacity Ratio of the Frame Column to the Infill Wall. For the partially infilled RC frame with rigid connection, the failure mode of the frame column is affected by the degree of lateral constraint from the infill to frame column. If the strength of the infill wall is relatively high, then the lateral constraint on the column is strong and the free segment of the column decreases, causing short column effect. Hence, the shear bearing capacity ratio of the frame column to the infill wall is an important parameter that affects the failure mode of the column [15].

This ratio can be expressed by the following equation:

$$
\xi=\frac{V_{\mathrm{C}}}{V_{\mathrm{W}}}
$$

where $V_{c}$ is the shear bearing capacity of the frame column and $V_{\mathrm{w}}$ is the shear bearing capacity of the infill wall. $\xi_{0}$ is defined as the critical ratio of the shear bearing capacity 
TABLE 4: Elastic parameters of the materials.

\begin{tabular}{|c|c|c|c|c|c|}
\hline Type & Masonry & Reinforcement & $\begin{array}{c}\text { Concrete used in } \\
\text { frame }\end{array}$ & $\begin{array}{l}\text { Concrete poured in } \\
\text { core column }\end{array}$ & $\begin{array}{l}\text { Polystyrene } \\
\text { foam board }\end{array}$ \\
\hline $\begin{array}{l}\text { Elastic modulus } \\
(\mathrm{MPa})\end{array}$ & 443 & $2 \times 10^{5}$ & $3 \times 10^{4}$ & $1.48 \times 10^{4}$ & 6.15 \\
\hline Poisson ratio & 0.315 & 0.3 & 0.2 & 0.25 & 0.5 \\
\hline
\end{tabular}

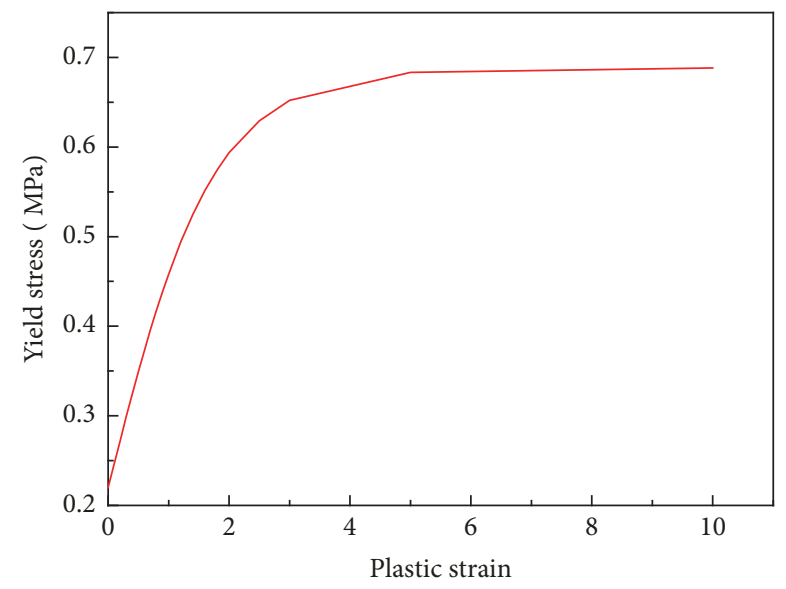

FIGURE 12: Yield stress versus plastic strain curve for polystyrene foam board.

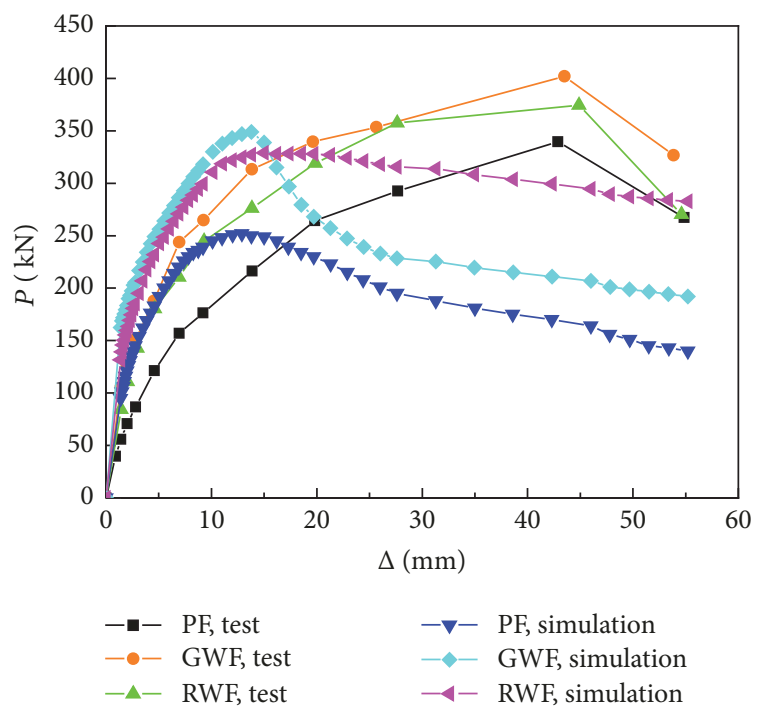

Figure 13: Load-displacement skeleton curves.

of the frame to the infill wall, which is associated with the connection mode between the infill and frame and the type and strength of the masonry. If $\xi \geq \xi_{0}$, the structure is a strong frame with weak infill; this results in a small lateral constraint on the frame. In this case, under a horizontal load, bending failure occurs in the frame column. If $\xi<\xi_{0}$, the structure will be a weak frame with strong infill, resulting in strong lateral constraint on the frame. In addition, the top of the wall became the fixed support of the column and the shear span ratio of the frame column decreased. It caused short column effect and shear failure.

\subsubsection{Influence of Shear Bearing Capacity Ratio of the Frame} Column to the Infill Wall on the Failure Mode of the Structure. Three nonlinear finite element models of specimens with rigid connection were established. The masonry height is 600 $\mathrm{mm}$ in all the three models, and the compression strengths of the masonry are $2 \mathrm{MPa}, 2.5 \mathrm{MPa}$, and $3 \mathrm{MPa}$, respectively. Figure 15 shows the calculated load-displacement curves for all the models. The images of plastic strain for loads up to the ultimate bearing capacity are shown in Figures 16 and 17.

The following observations can be made from Figures 15-17.

(1) With the increase in masonry strength, the bearing capacity and stiffness of the structure increase, but the structural ductility decreases in the case of rigid connection and partial infill.

(2) For the structure with masonry compression strength of $2 \mathrm{MPa}$, a relatively larger plastic strain appears on the column end and the beam end, and bending failure occurs. For the structure with masonry compression strength of $2.5 \mathrm{MPa}$ and $3 \mathrm{MPa}$, the maximum value of plastic strain appears at the centre of the free segment of the right column, and shear failure occurs in the column. This may be attributed mainly to the increase in the lateral constraint of the infill wall to the column with the increasing in masonry compression strength. When the masonry compression strength increases to a certain extent, the clamping effect of the wall to the frame column increases, and the shear span ratio of the column free segment reduces, leading to an increase in stiffness and decrease in energy dissipation capacity. In the end, the stirrups yield ahead of the longitudinal reinforcements owing to insufficient shear capacity and short column effect.

(3) The reason for the reduction in the structure ductility is that the short column effect causes brittle shear failure associated with the low deformation capacity of the structure in the case of a strong infill wall surrounded by a weak frame.

(4) For the infill wall, the diagonal strut mechanism is evident, and the plastic deformation is concentrated mainly on the infill diagonal from the loading corner to the bottom of the left column.

The values of the shear bearing capacity ratio of the frame column to the infill wall for the three models are listed in Table 5. From the results, a value of 2.0 is suggested for the critical shear bearing capacity ratio $\left(\xi_{0}\right)$ in the case of a partially infilled frame with rigid connection. 


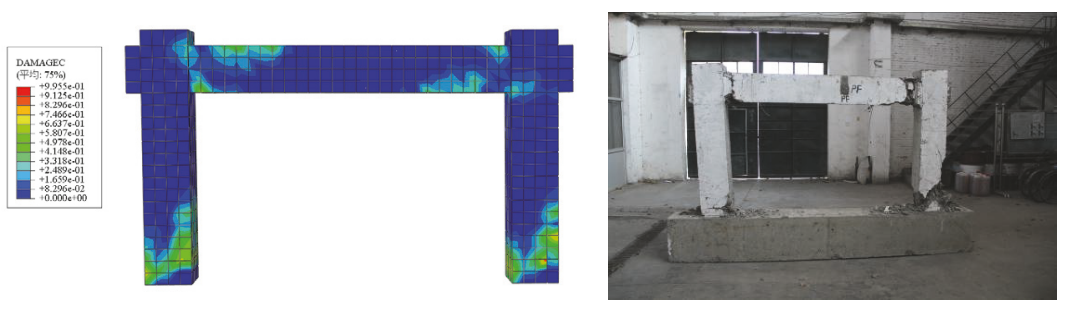

(a) Specimen PF

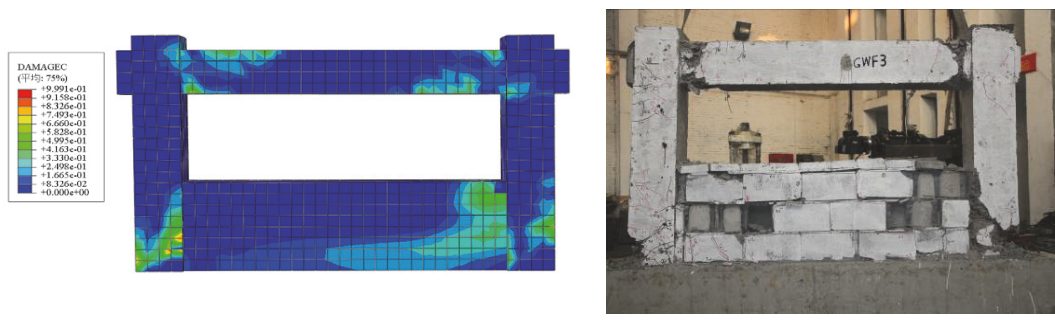

(b) Specimen GWF

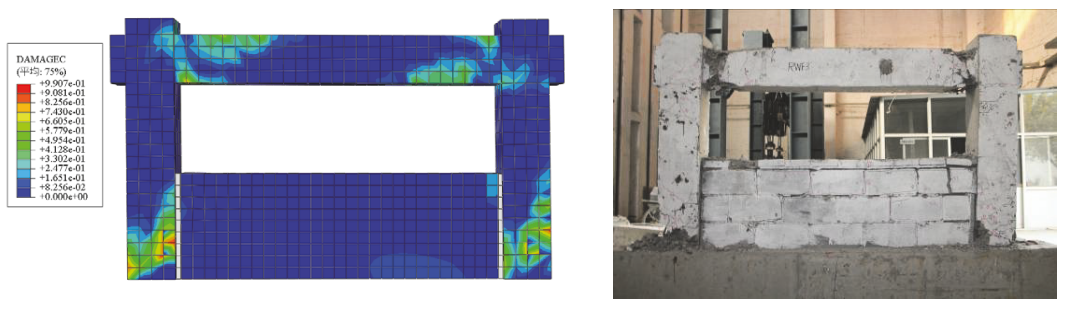

(c) Specimen RWF

FIGURE 14: Plastic damage in compression from modeling and failure phenomenon from experiment.

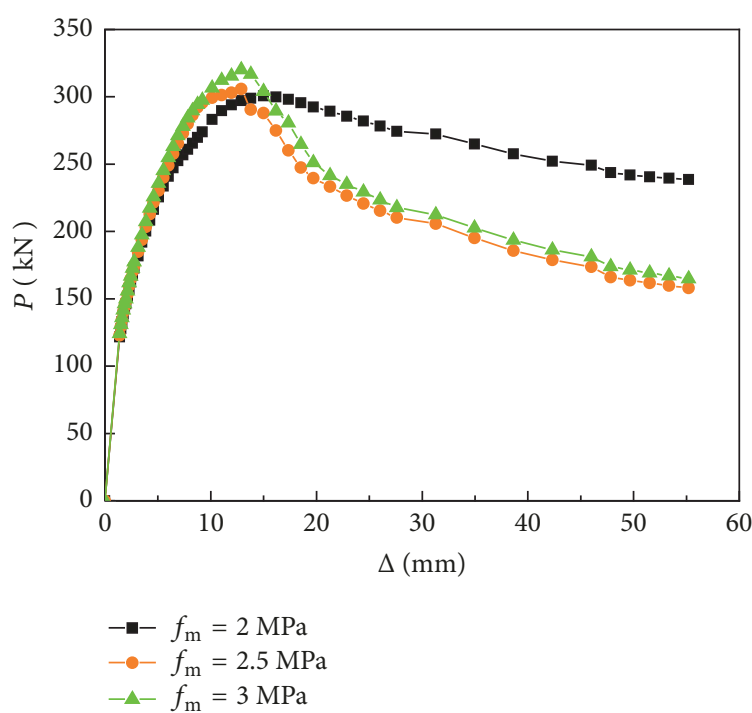

FIGURE 15: Calculated load-displacement curves.

3.3. Influence of Infill Height on the Failure Mode of the Structure in the Case of Rigid Connection. Investigations were conducted for infill heights $H_{\mathrm{w}}$ of $0 \mathrm{~mm}, 300 \mathrm{~mm}, 600 \mathrm{~mm}$, $900 \mathrm{~mm}$, and $1230 \mathrm{~mm}$ and masonry strengths $f_{\mathrm{m}}$ of $2 \mathrm{MPa}$ and $3 \mathrm{MPa}$ used in the finite element models. The filling rate is defined as the ratio of infill height $H_{\mathrm{w}}$ to the clear height $H$ of the frame column. The filling rates used in the investigation were $0,0.25,0.5,0.75$, and 1 , respectively, for the five infill heights mentioned above. The load-displacement curves of the models are shown in Figure 18. The plastic strain in the bare frame for loads up to the ultimate bearing capacity is shown in Figure 19 and that in the partially infilled frames is shown in Figures 20-23.

From the results, the following conclusions can be drawn.

(1) For masonry-infilled frames with rigid connection, the presence of masonry infill increases the stiffness and the bearing capacity of the structure; the greater the filling rate is, the higher the increase is.

(2) When the masonry strength is lower (e.g., 2MPa), irrespective of the filling rate, there is no increase in the ductility of the structure. When the masonry strength is higher (e.g., 3MPa), the ductility of the structure decreases with the increasing of filling rate, and the decline branch of the load-displacement curve is steeper (except for a filling rate of $1)$.

(3) When the filling rate is 0 , a large plastic strain is observed at the ends of the column and beam. When the filling rate is 1 , the diagonal strut of the infill wall is evident, and a large plastic strain is observed mainly on the column and beam ends. When the filling rate is 0.25 , the infill wall does not affect the frame significantly, and the distribution of plastic strain is similar to that in the case of filling rates of 0 


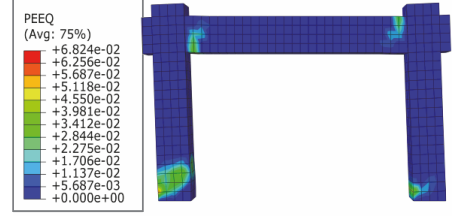

(a) Masonry strength $f_{\mathrm{m}}=2 \mathrm{MPa}$

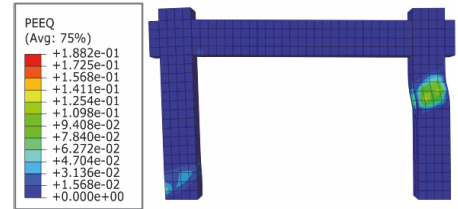

(b) Masonry strength $f_{\mathrm{m}}=2.5 \mathrm{MPa}$

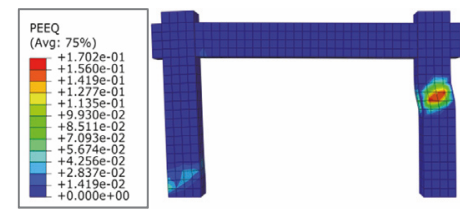

(c) Masonry strength $f_{\mathrm{m}}=3 \mathrm{MPa}$

FIGURE 16: Plastic strain in RC frames.

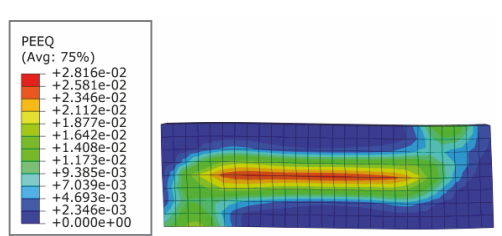

(a) Masonry strength $f_{\mathrm{m}}=2 \mathrm{MPa}$

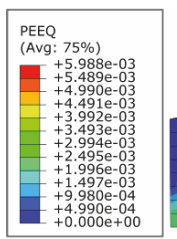

(b) Masonry strength $f_{\mathrm{m}}=2.5 \mathrm{MPa}$

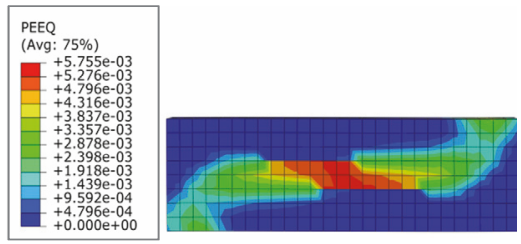

(c) Masonry strength $f_{\mathrm{m}}=3 \mathrm{MPa}$

Figure 17: Plastic strain in infill walls.

TABLE 5: Shear bearing capacity ratio of the frame column to the infill wall $(\xi)$.

\begin{tabular}{lcccc}
\hline $\begin{array}{l}\text { Masonry strength } \\
(\mathrm{MPa})\end{array}$ & $\begin{array}{c}V_{c} \\
(\mathrm{kN})\end{array}$ & $\begin{array}{c}V_{w} \\
(\mathrm{kN})\end{array}$ & $\begin{array}{c}\text { Short } \\
\text { column } \\
\text { failure }\end{array}$ \\
\hline 2 & 225 & 111.7 & 2.01 & No \\
\hline 2.5 & 225 & 139.7 & 1.61 & Yes \\
\hline 3 & 225 & 167.6 & 1.34 & Yes \\
\hline
\end{tabular}

* According to the literature [23], $V_{\mathrm{c}}=(0.1 /(\lambda+0.1)) f_{\mathrm{c}} b h_{0}+0.8 f_{\mathrm{yv}}\left(A_{\mathrm{sv}} / s\right) h_{0}+0.07 N$, where $\lambda$ is the shear span ratio, $\mathrm{b}$ is the width of the column, h0 is the effective height of the cross section of the column, fc is the axial compressive strength of the concrete, fyv is the yield strength of the stirrup, Asv is the cross-sectional area of the stirrup, $s$ is the spacing of the stirrups, and $\mathrm{N}$ is the axial compression force.

* According to the Chinese Code for Design of Masonry Structures (GB 50003-2011), $V_{\mathrm{w}}=f_{\mathrm{vm}} A$, where $f_{\mathrm{vm}}$ is shear strength of the masonry-infilled wall, $f_{\mathrm{vm}}=0.113 f_{\mathrm{m}}$, and $A$ is the cross-sectional area of the wall.

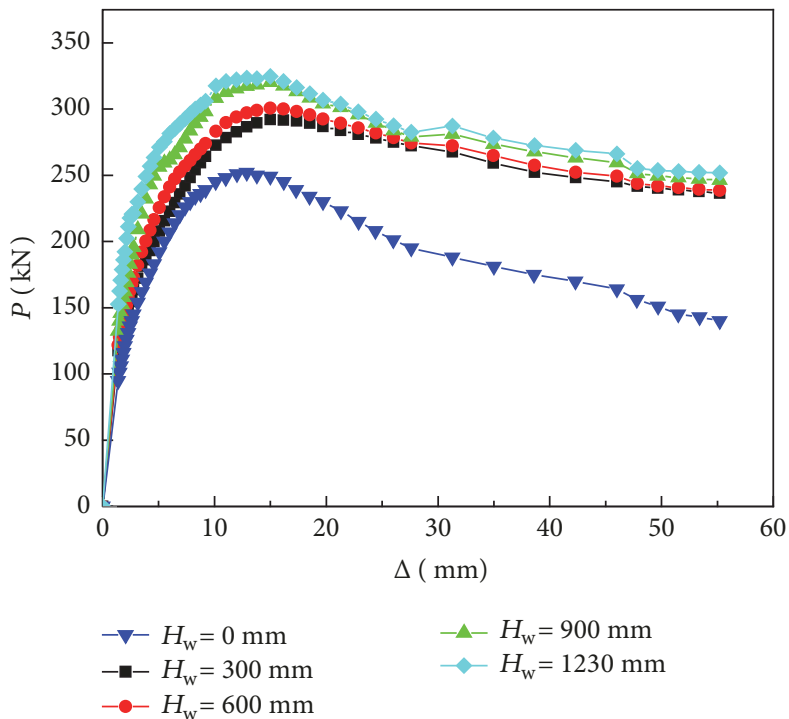

(a) Masonry strength of $2 \mathrm{MPa}$

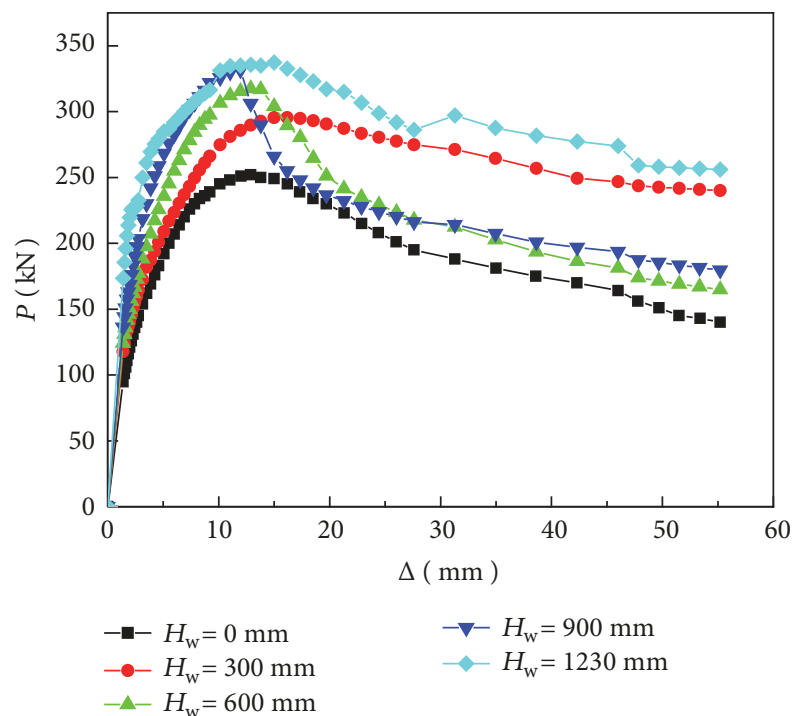

(b) Masonry strength of $3 \mathrm{MPa}$

FIGURE 18: Load-displacement curves. 


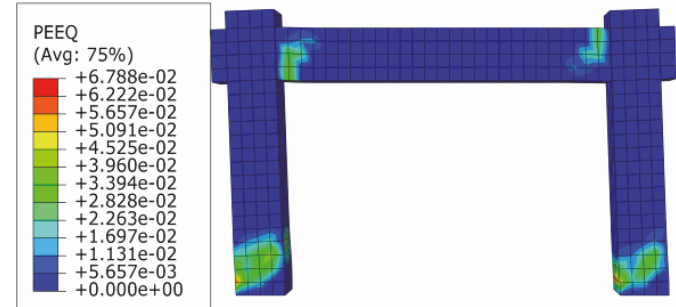

FIGURE 19: Plastic strain in bare frame.

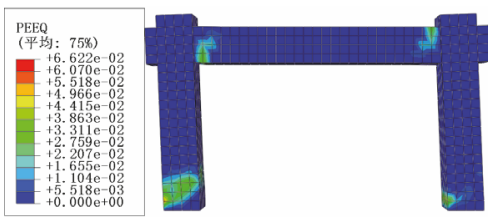

(a) $H_{\mathrm{w}}=300 \mathrm{~mm}$

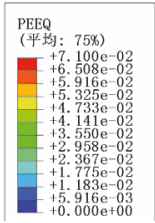

(b) $H_{\mathrm{w}}=900 \mathrm{~mm}$

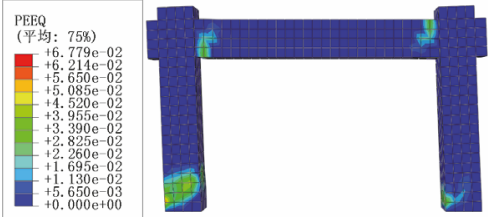

(c) $H_{\mathrm{w}}=1230 \mathrm{~mm}$

FIGURE 20: Plastic strain in frames partially infilled with masonry $\left(f_{\mathrm{m}}=2 \mathrm{MPa}\right)$.

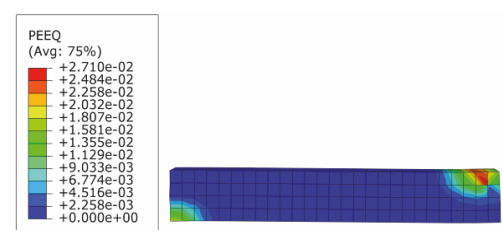

(a) $H_{\mathrm{w}}=300 \mathrm{~mm}$

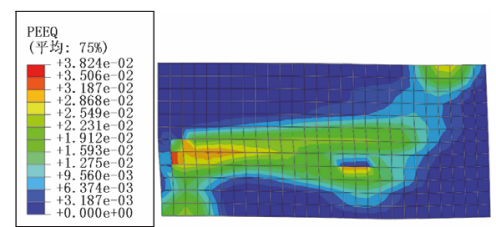

(b) $H_{\mathrm{w}}=900 \mathrm{~mm}$

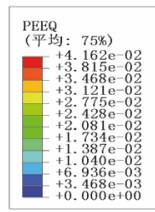

(c) $H_{\mathrm{w}}=1230 \mathrm{~mm}$

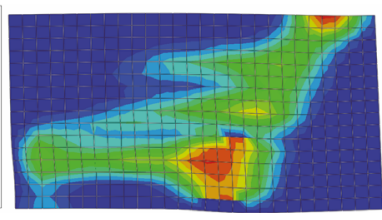

Figure 21: Plastic strain in infill walls $\left(f_{\mathrm{m}}=2 \mathrm{MPa}\right)$.

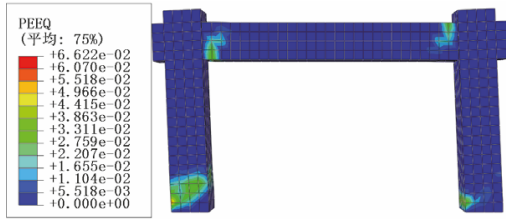

(a) $H_{\mathrm{w}}=300 \mathrm{~mm}$

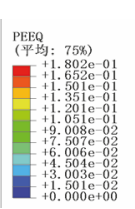

(b) $H_{\mathrm{w}}=900 \mathrm{~mm}$
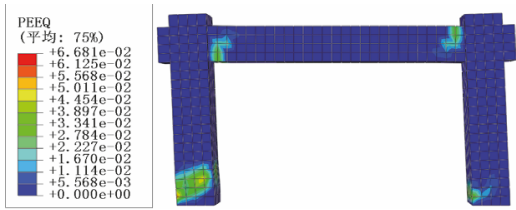

(c) $H_{\mathrm{w}}=1230 \mathrm{~mm}$

FIGURE 22: Plastic strain in frames partially infilled with masonry $\left(f_{\mathrm{m}}=3 \mathrm{MPa}\right)$.

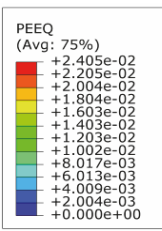

(a) $H_{\mathrm{w}}=300 \mathrm{~mm}$
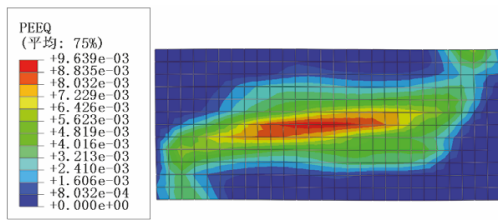

(b) $H_{\mathrm{w}}=900 \mathrm{~mm}$
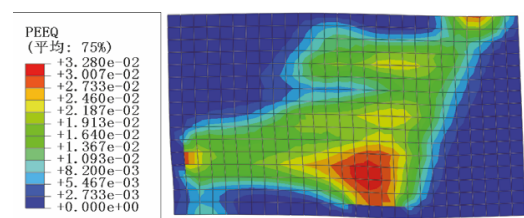

(c) $H_{\mathrm{w}}=1230 \mathrm{~mm}$

Figure 23: Plastic strain in infill walls $\left(f_{\mathrm{m}}=3 \mathrm{MPa}\right)$. 


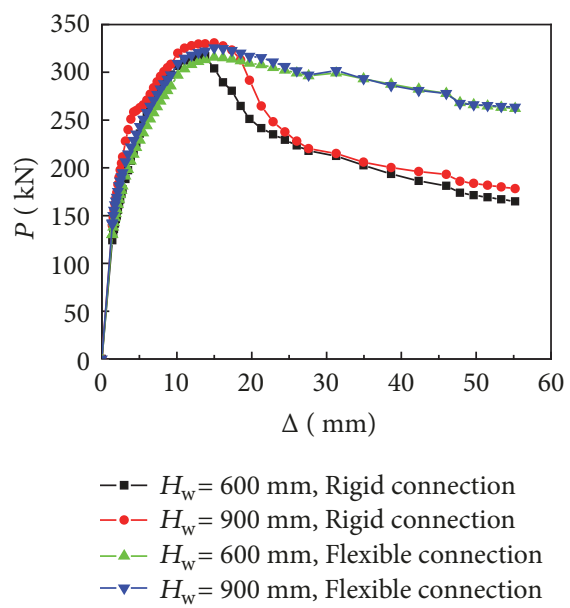

Figure 24: Load-displacement curves of models with different connections.

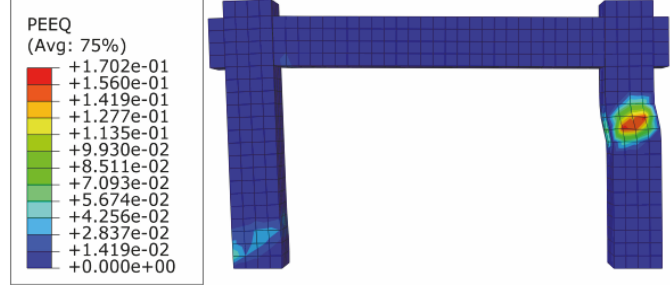

(a) Infill height of $600 \mathrm{~mm}$ with rigid connection

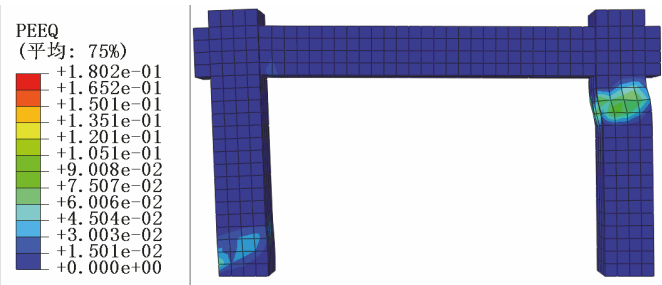

(c) Infill height of $900 \mathrm{~mm}$ with rigid connection

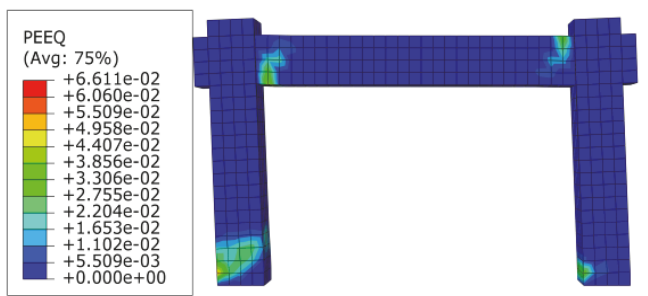

(b) Infill height of $600 \mathrm{~mm}$ with flexible connection

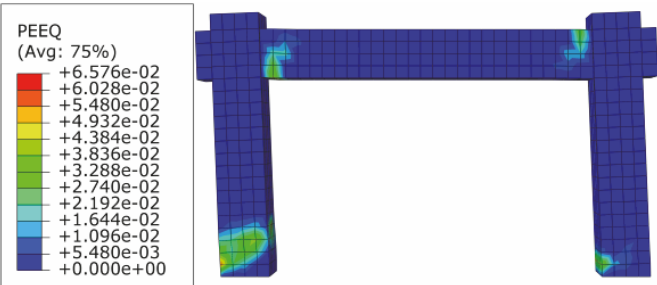

(d) Infill height of $900 \mathrm{~mm}$ with flexible connection

FIGURE 25: Plastic strain in RC frame with different connection modes.

and 1. The higher the infill height is, the more easily the shear failure occurs because of the short column effect. When the filling rates are 0.5 and 0.75 , the shear span ratios of the free segment of the column were 1.3 and 0.8 , respectively, which lie in the short column range $(\lambda \leq 2)$.

(4) The infill height is an important factor that affects the failure mode of the structure. In real structures, a value greater than 2.0 is recommended for the shear span ratio of the free segment of the column.

3.4. Influence of Connection Mode between the Frame and the Infill Wall on the Failure Mode of the Structure. Two connection modes between the wall and frame, i.e., flexible connection and rigid connection, were investigated using finite element models. The compression strength of the masonry was $3 \mathrm{MPa}$, and the heights of the infill wall were 600 $\mathrm{mm}$ and $900 \mathrm{~mm}$. The load-displacement curves are shown in Figure 24. The comparison of plastic strains for loads up to the ultimate bearing capacity is shown in Figures 25 and 26, and the stresses in the steel bars are shown in Figure 27.

From Figures 24-27, the following observations can be made.

(1) The bearing capacity and stiffness of the structure with rigid connection are higher than those of the corresponding structure with flexible connection; however, the difference is not large, especially when the filling rate is low.

(2) The displacement ductility of the specimen with flexible connection is greater than that of the corresponding specimen with rigid connection; this is favourable for energy dissipation and plastic deformation under a severe earthquake.

(3) In case of the infilled RC frame with flexible connection, because of the decreasing of the wall-frame interaction and the reduction of lateral constraint from the wall to the column, the short column effect which occurs easily in case of rigid connection is prevented. Therefore, the flexible 

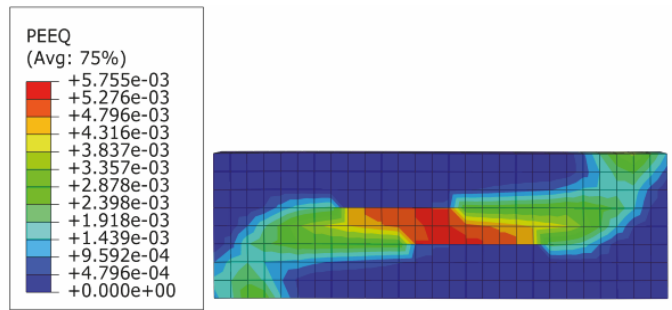

(a) Infill height of $600 \mathrm{~mm}$ with rigid connection

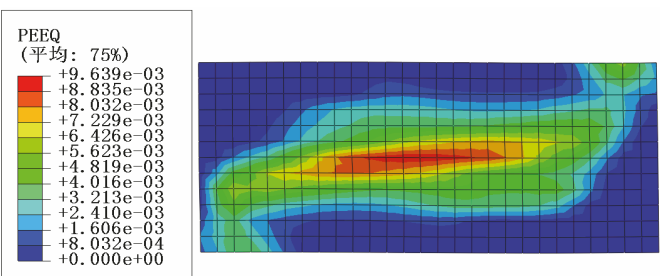

(c) Infill height of $900 \mathrm{~mm}$ with rigid connection

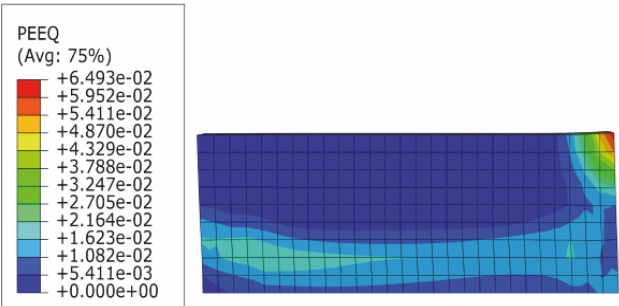

(b) Infill height of $600 \mathrm{~mm}$ with flexible connection

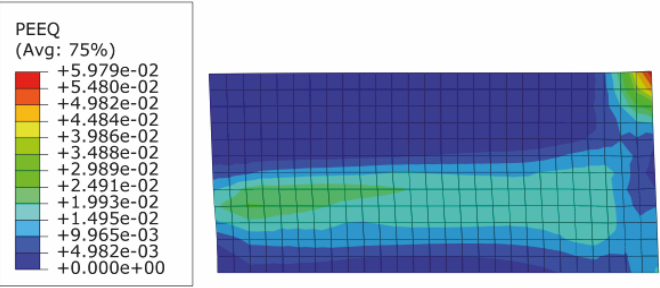

(d) Infill height of $900 \mathrm{~mm}$ with flexible connection

FIGURE 26: Plastic strain in infill wall with different connection modes.

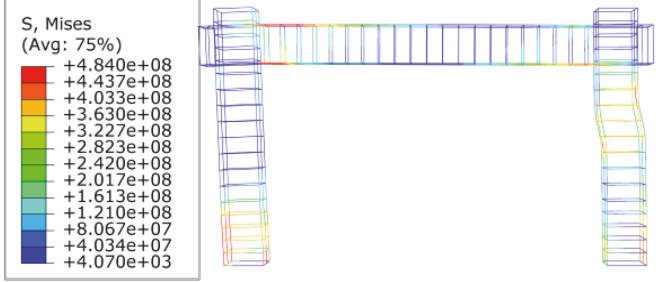

(a) Infill height of $600 \mathrm{~mm}$ with rigid connection

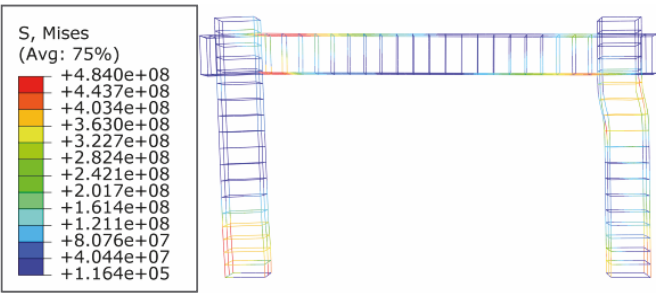

(c) Infill height of $900 \mathrm{~mm}$ with rigid connection

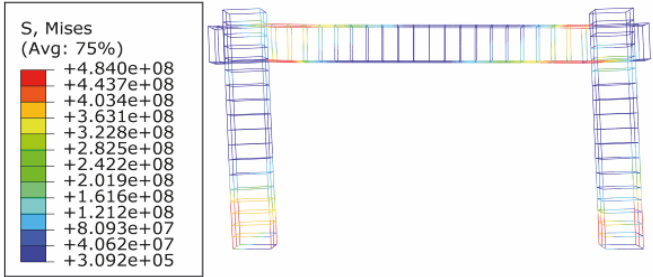

(b) Infill height of $600 \mathrm{~mm}$ with flexible connection

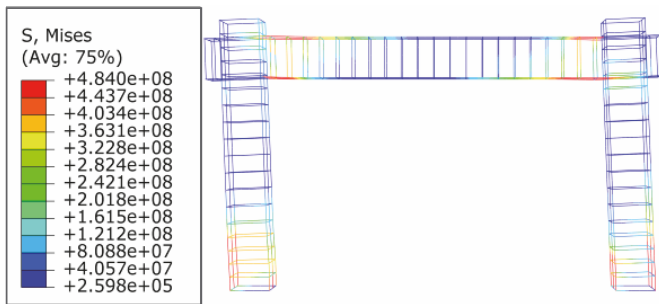

(d) Infill height of $900 \mathrm{~mm}$ with flexible connection

FIGURE 27: Stresses in reinforcement members in different connection modes.

structure has better seismic resistance, and the using of flexible connection can also reduce the damage to the infill wall which is beneficial to the working performance of the structure as a whole.

\section{Conclusions}

Experimental tests and nonlinear finite element simulation were conducted to study the effects of the infill walls and wallframe connections. The following conclusions were drawn:

(i) The infill wall can increase the strength, stiffness, and ductility of the frame structure. However, in the case of a partially infilled frame with rigid connection, when the masonry strength and the infill height are increased, the ductility of the frame structure may decrease owing to short column effect.

(ii) The infill height $H_{\mathrm{w}}$ and the shear bearing capacity ratio of the frame column to the infill wall have influence on mechanical performance and failure modes of the frame column. In the case of rigid connection between the wall and frame, with the increase in $H_{\mathrm{w}}$ and decrease in $\xi$, the lateral restraint on the frame column increases, and the shear span ratio of the free segment of the frame column decreases; this results in short column effect and leads to the occurrence of brittle shear failure. A value of 2.0 is suggested for the critical shear bearing capacity ratio $\xi_{0}$. When $\xi<2.0$ and the shear span ratio of the free segment of the 
column $\lambda \leq 2.0$, short column effect will occur, and hence appropriate measures should be taken to avoid failure.

(iii) The mechanical performance and failure modes of the frame column are affected by the connection mode between the wall and frame. With flexible connection, the interaction between the wall and frame is insignificant, and the lateral constraint from the wall to theframe is weakened, which reduces or eliminates the short column effect that occurs in case of rigid connection, resulting in a better seismic performance.

\section{Data Availability}

The data used to support the findings of this study are included within the article.

\section{Conflicts of Interest}

The authors declare that there are no conflicts of interest regarding the publication of this paper.

\section{Acknowledgments}

The research described in this paper was financially supported by the National Natural Science Foundation of China under Grant nos. 51678389 and 51408400.

\section{References}

[1] Y.-J. Chiou, J.-C. Tzeng, and Y.-W. Liou, "Experimental and analytical study of masonry infilled frames," Journal of Structural Engineering, vol. 125, no. 10, pp. 1109-1117, 1999.

[2] A. Stavridis and P. B. Shing, "Finite-element modeling of nonlinear behavior of masonry-infilled RC frames," Journal of Structural Engineering, vol. 136, no. 3, pp. 285-296, 2010.

[3] I. Koutromanos, A. Stavridis, P. B. Shing, and K. Willam, "Numerical modeling of masonry-infilled RC frames subjected to seismic loads," Computers \& Structures, vol. 89, no. 11-12, pp. 1026-1037, 2011.

[4] K. M. Dolatshahi and A. J. Aref, "Two-dimensional computational framework of meso-scale rigid and line interface elements for masonry structures," Engineering Structures, vol. 33, no. 12, pp. 3657-3667, 2011.

[5] B. Moaveni, A. Stavridis, G. Lombaert, J. P. Conte, and P. B. Shing, "Finite-element model updating for assessment of progressive damage in a 3-story infilled RC Frame," Journal of Structural Engineering (United States), vol. 139, no. 10, pp. 1665-1674, 2013.

[6] P. G. Asteris, D. M. Cotsovos, C. Z. Chrysostomou, A. Mohebkhah, and G. K. Al-Chaar, "Mathematical micromodeling of infilled frames: state of the art," Engineering Structures, vol. 56, pp. 1905-1921, 2013.

[7] V. Bahreini, T. Mahdi, and M. Najafizadeh, "Numerical Study on the In-Plane and Out-of-Plane Resistance of Brick Masonry Infill Panels in Steel Frames," Shock and Vibration, vol. 2017, 2017.

[8] L. Cavaleri and F. Di Trapani, "Prediction of the additional shear action on frame members due to infills," Bulletin of Earthquake Engineering, vol. 13, no. 5, pp. 1425-1454, 2015.

[9] F. Di Trapani, G. Macaluso, L. Cavaleri, and M. Papia, "Masonry infills and RC frames interaction: Literature overview and state of the art of macromodeling approach," European Journal of Environmental and Civil Engineering, vol. 19, no. 9, pp. 1059-1095, 2015.

[10] B. Zhao, F. Taucer, and T. Rossetto, "Field investigation on the performance of building structures during the 12 May 2008 Wenchuan earthquake in China," Engineering Structures, vol. 31, no. 8, pp. 1707-1723, 2009.

[11] G. Manfredi, A. Prota, G. M. Verderame, F. De Luca, and P. Ricci, "2012 Emilia earthquake, Italy: reinforced concrete buildings response," Bulletin of Earthquake Engineering, vol. 12, no. 5, pp. 2275-2298, 2014.

[12] H. Varum, A. Furtado, H. Rodrigues, J. Dias-Oliveira, N. VilaPouca, and A. Arêde, "Seismic performance of the infill masonry walls and ambient vibration tests after the Ghorka 2015, Nepal earthquake," Bulletin of Earthquake Engineering, vol. 15, no. 3, pp. 1185-1212, 2017.

[13] E. K. Vahidi and M. M. Malekabadi, "Conceptual investigation of short-columns and masonary infill frames effect in the earthquakes," World Academy of Science, Engineering and Technology, vol. 59, pp. 119-124, 2009.

[14] Y. P. Yuen and J. S. Kuang, "Nonlinear seismic responses and lateral force transfer mechanisms of RC frames with different infill configurations," Engineering Structures, vol. 91, pp. 125140, 2015.

[15] Q. Huang, Z. Guo, and J. S. Kuang, "Designing infilled reinforced concrete frames with the 'strong frame-weak infill' principle," Engineering Structures, vol. 123, pp. 341-353, 2016.

[16] M. Preti, N. Bettini, and G. Plizzari, "Infill walls with sliding joints to limit infill-frame seismic interaction: Large-scale experimental test," Journal of Earthquake Engineering, vol. 16, no. 1, pp. 125-141, 2012.

[17] J. S. Kuang and Z. Wang, "Cyclic load tests of RC frame with column-isolated masonry infills," in Proceedings of the 2nd European Conference on Earthquake Engineering and Seismology, Istanbul, Turkey, 2014.

[18] X. Palios, M. N. Fardis, E. Strepelias, and S. N. Bousias, "Unbonded brickwork for the protection of infills from seismic damage," Engineering Structures, vol. 131, pp. 614-624, 2017.

[19] M. Aliaari and A. M. Memari, "Analysis of masonry infilled steel frames with seismic isolator subframes," Engineering Structures, vol. 27, no. 4, pp. 487-500, 2005.

[20] Y. Cheng, M. Liu, X.-W. Liu, and B. Wang, "Shaking test research on connection modes between block infill wall and frame beam," Journal of Harbin Institute of Technology (New Series), vol. 18, no. 5, pp. 123-129, 2011.

[21] M. Preti and V. Bolis, "Masonry infill construction and retrofit technique for the infill-frame interaction mitigation: Test results," Engineering Structures, vol. 132, pp. 597-608, 2017.

[22] H. Zhang, J. S. Kuang, and T. Y. P. Yuen, "Low-seismic damage strategies for infilled RC frames: shake-table tests," Earthquake Engineering \& Structural Dynamics, vol. 46, no. 14, pp. 24192438, 2017.

[23] Research Group on Shear Strength, "The shear strength of reinforced concrete frame column," Journal of Building Structures, vol. 3, pp. 23-35, 1987 (Chinese).

[24] X. J. Zhou, D. D. Xu, and J. K. Song, "Study on compressive mechanical performance and nonlinear finite element analysis of fly-ash thermal insulation hollow block masonry," Earthquake Engineering and Engineering Vibration, vol. 35, no. 4, pp. 262-270, 2015 (Chinese).

[25] A. H. Akhaveissy and C. S. Desai, "Unreinforced Masonry Walls: Nonlinear Finite Element Analysis with a Unified Constitutive Model," Archives of Computational Methods in Engineering: State-of-the-Art Reviews, vol. 18, no. 4, pp. 485-502, 2011. 


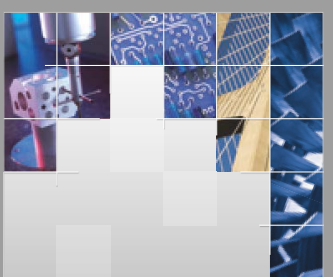

\section{Enfincering}
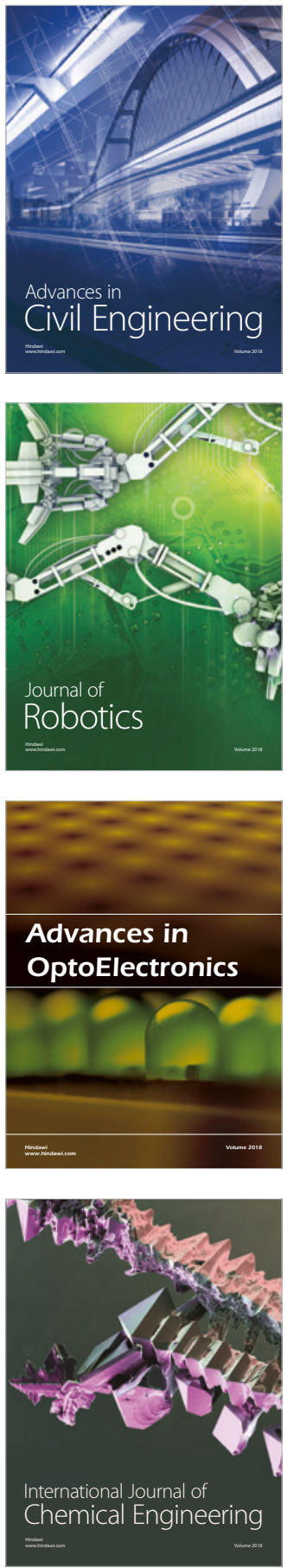

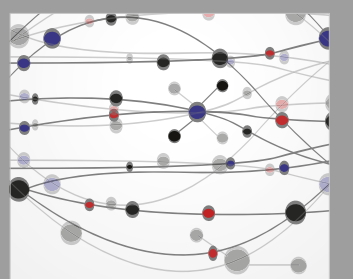

\section{Rotating \\ Machinery}

The Scientific World Journal

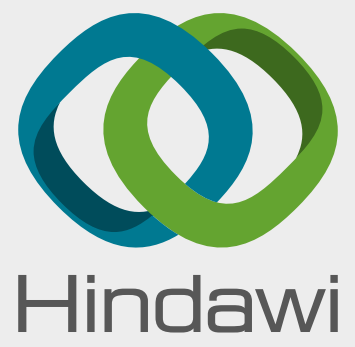

Submit your manuscripts at

www.hindawi.com
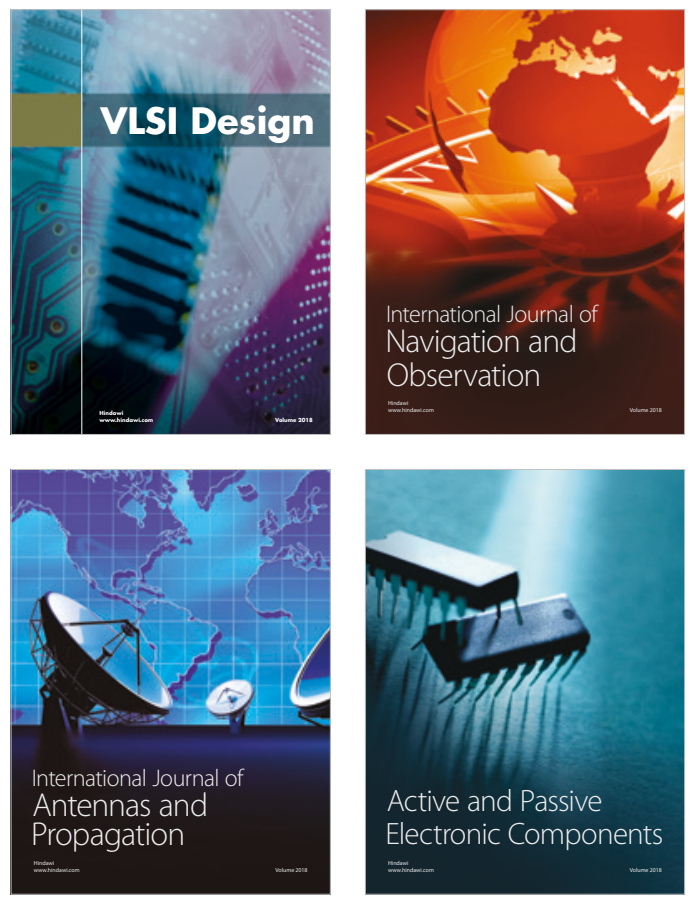
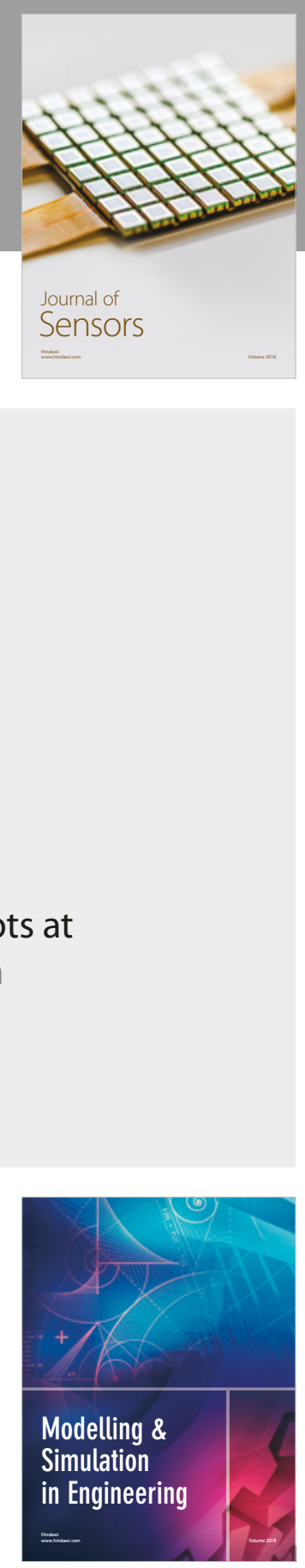

\section{Advances \\ Multimedia}
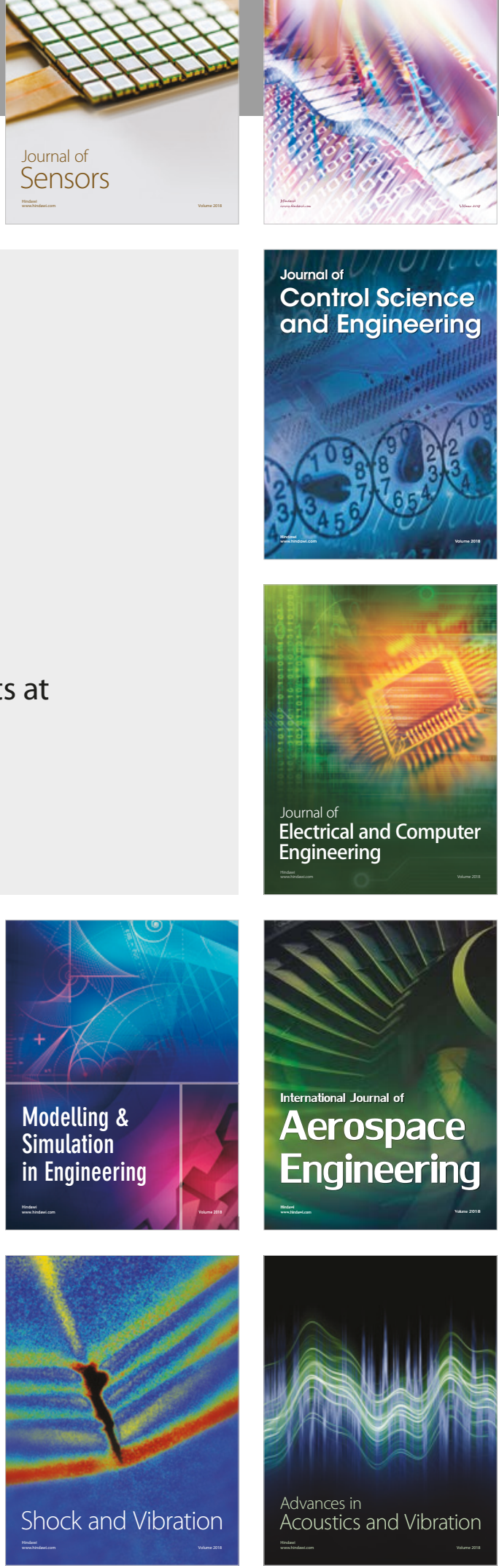